\title{
What's in a Name? Reading the Character of Mary/Moira in Jane Urquhart's Away
}

\author{
Audrey Robitaillié \\ Queen's University Belfast
}

Copyright (c) 2016 by Audrey Robitaillié. This text may be archived and redistributed both in electronic form and in hard copy, provided that the author and journal are properly cited and no fee is charged for access.

\begin{abstract}
This article analyses the various connotations of the name of the protagonist in Jane Urquhart's Irish-Canadian novel Away, first published in 1993. The heroine Mary changes her name to Moira at the start of the book, which leads the reader to ponder on the significance of these names. By exploring the classical, topographical, naval, linguistic and religious undertones of Mary/Moira, this study seeks to demonstrate how the Canadian author conveys notions of postcolonialism throughout her novel with the choice of a character's name.
\end{abstract}

Key Words. Jane Urquhart, Irish diaspora, Canadian literature, postcolonialism, Irish folklore.

Resumen. Este artículo analiza las diversas connotaciones del nombre de la protagonista de la novela canadiense irlandesa de Jane Urquhart Away, publicada por primera vez en 1993. La heroína Mary cambia su nombre por el de Moira al inicio del libro, lo que lleva al lector a reflexionar sobre el significado de estos nombres. Al explorar los matices clásicos, topográficos, navales, lingüísticos y religiosos de Mary/Moira, este estudio pretende demostrar cómo la autora canadiense transmite nociones de poscolonialismo a lo largo de su novela con la elección del nombre de un personaje.

Palabras clave. Jane Urquhart, diáspora irlandesa, literatura canadiense, postcolonialismo, folklore irlandés.

\section{Introduction}

Jane Urquhart's Away (1993) is centred on the character of Mary, who is thought to be "away with the fairies", in a context of Famine and emigration. The novel, starting on Rathlin Island in the north of Ireland, ends in Ontario, and thus highlights the double meaning of its title. As a young woman on the island, Mary finds a dying sailor washed ashore after a shipwreck. Believing that he comes from another world, she falls in love with him and decides that her name has changed: "she recognized, immediately, that he came from an otherworld island, assumed that he had emerged from the water to look for her, and knew that her name had changed, in an instant, from Mary to Moira" (Urquhart 2002: 8). From then on, she is considered "away" by the rest of the community, that is, "away with the fairies", gone to the Otherworld. In the islanders' minds, the being who wanders on the shore and speaks to no one but the sea is not Mary but a changeling, a substitute for the stolen woman. She later marries a schoolteacher, Brian O'Malley, to whom she bears a child, Liam. During the Great Famine, the family is forced to emigrate to Canada, where a daughter, Eileen, 
is born. The narration focuses alternatively on Mary, Eileen and the latter's granddaughter, Esther, spanning four generations of women who have, one way or another, been "away". The Canadian writer plays on the meanings of the word itself to raise issues of belonging and identity in her fourth book.

The very fact that the protagonist of the novel changes her name at the start of the narrative prompts the reader to wonder what the significance of this name is. In the same fashion that Urquhart plays on the various meanings of the term "away" for the title of her novel, it seems that the numerous connotations of the name Mary/Moira are used by the author to develop a postcolonialist stance.

Postcolonialism is a political, social and cultural movement which aspires to look back on the colonial years with a new focus, not on the coloniser and dominant power any more, but on the oppressed and repressed peoples and cultures. Postcolonialism has thus seen a renewed interest in local cultures, languages, folklore, etc., which is also a feature of nationalist movements. The postcolonial current is characterised by a focus on the disempowered minorities, and on the effects of colonialism. Urquhart wrote Away from a perspective which criticises the colonial takeovers of Canada and Ireland (Sugars 2003: 5), though admittedly rather problematically (Goldman 2010: 133), while looking for a way of reconciling the various heritages brought together by colonisation. According to Libby Birch, "Urquhart draws on themes of muted cultures who can know a rebirth and thus emulates Lady Gregory and Yeats who play a vital role in effecting the Celtic revival in Ireland" (Birch 1997: 118). The novel indeed focuses on the Irish immigrants to Canada and their interaction with indigenous peoples, rather than with the dominant powers in place in the Dominion at the time. Urquhart diverges from the canonical models and shifts the focus to the unspoken stories of colonialism, of which Mary's and her Native friend Exodus's are thought of as archetypes. As an emigrant forced out of her country by colonialism and as a woman, Mary doubly personifies such a figure. The fact that she subverts the codes of traditional writing by being an unconventional mother partakes of postcolonialism as well (Loomba 2010: 215-6). As has been noted previously, "while Away deconstructs the imperial representations of the colonised and the coloniser, the individual is rendered visible" (Branach-Kallas 2003: 140).

Mary is the model of the postcolonial character in the narrative and this is expressed through the very choice of her double name of Mary/Moira in the novel. This article will first study the classical influence of the name before looking at the geographical elements. It will then focus on the ship imagery, to finish with the linguistic and religious connotations of Mary/Moira, in order to analyse how Urquhart uses the name of her character to convey a sense of postcolonialism throughout the book.

\section{A Classical Heritage}

As has been remarked in previous studies on Away (Birch 1997: 116), moira is an ancient Greek word, meaning "destiny" or "share", "portion", expressing the idea that destiny allocates a certain quantity of good and evil, of happiness and sorrow, of life and death to each human being. The Moira is the law in ancient Greece according to which their lot is assigned to each individual. It was embodied by the three faceless Fates, Clotho, Lachesis and Atropos, whose hymns to the dead were known as Moirologhia in Greek. Their action on human destinies were represented by a thread, which one spun, the second measured and the third eventually cut. Moira sometimes appears as a synonym for death (Karamanous 2013: 293). Echoing Mary's obsession with the dead sailor, the Moirai were also thought of as a trinitarian form of the goddess of love, Aphrodite, leading Anne Compton to write that "Mary O'Malley is the mythic figure of death and renewal" (Compton 2005: 139). The first page of the novel reads, after an enumeration of the characteristics of the O'Malley women: "That is the way it was for the women of this family. It was part of their destiny" (Urquhart 2002: 3). As pointed out in the very first paragraphs of the book, the fate of the O'Malley family, struck, like innumerable others, by the Great Famine in Ireland and then the plight of the poor settlers having to build themselves a new life from scratch in North America seems to echo the Greek meaning of Mary's other name.

That moira means destiny in Greek also brings a sense of tragedy to Away. The helpless- 
ness of humans facing events brought about by Fate creates a tragic effect. The latter highlights the limits of the human condition, that against which men and women cannot fight, however noble and brave their behaviours. As Ruth Scodel notes: "The entire tragic tradition, from Greek tragedy onward, concerns itself with some core issues: the vulnerability of human life; the value of facing the limits of our control with courage; and the powerful, sometimes inescapable, effect of our decisions" (Scodel 2010: 7). That the family inevitably had to emigrate because of the Famine illustrates this tragic sense around which the narrative is centred. By focusing the narrative on a poor Irish settler family, driven away from their homes by the forces of colonialism, the writer is also taking a postcolonial stance. The fate which is referred to through Mary's other name is an allegory for the colonial power against which the O'Malleys struggle.

The novel also recurrently refers to the "curse of the mines" (12), a "desecration of landscape for profit" in the words of Herb Wyile (1999: 29). The curse of "awayness", by which nearly all women in the family are affected, is evoked implicitly as well. The O'Malleys in Canada are first allocated their plot of land on the Canadian Shield where the soil is not fit for agriculture. After the deaths of their parents, the children Liam and Eileen are able to sell this land to a gold prospector who turns out to be their parents' former landlord in Ulster, Osbert Sedgewick. This results in the curse of the mines being brought on the family, as Eileen learns (225). The siblings settle along the lake where Liam can finally become the farmer he had always dreamt of being. But a few generations later, Eileen's granddaughter Esther remains alone in the big ancestral house on the eve of her eviction. A neighbouring quarry is in fact about to swallow the family fields, garden, orchard and house. The curse of the mines is thus a leitmotif in the novel, leading the O'Malleys to move homes several times throughout their history $(349,355)$. Since this is how the novel ends, it gives the reader a sense that the family could not have escaped this fate, that this moira was meant to be.

The same is true of the "curse of awayness", the latter being a term coined by Urquhart herself (Urquhart 1995: 11). As Eileen explains to her granddaughter in memories that Esther recalls at the end of the book (354-5), all the women of the family have been "away", except for Deirdre, Eileen's daughter and Esther's mother. The first of them, Mary, went away to the Otherworld the day she encountered the dying sailor on the beach on Rathlin Island, before going away with her family to Canada, fleeing the Famine. Her daughter, Eileen, got carried away by her lover, Aidan Lanighan, and politics she did not quite understand when she was a young woman, before living as a recluse in her room overlooking the lake for the rest of her life after he left her. Esther reproduces her grandmother's behaviour too, inheriting the house and the room, as well as the curse. The awayness that runs in the family is the connecting thread running through the novel, it is the O'Malley women's moira. Besides, just like the three Moirai weaving the thread of human existence, three women in the family are cursed with awayness: Mary, Eileen and Esther. As Marcia Anne Bell rightfully notes (1997: 232), much more could be said about the importance of the number three in the novel.

Jane Urquhart remarks that the name has a particular significance in the novel: "the word Moira was not just another name for one of my characters, but [...] it was a word that had resonance, and that was working on several levels. It had profound meaning in an ancient classical language, and it had a meaning in the new landscape, the landscape of the new world" (Ferri 2000: 151). Because of its links with classical culture and the deep connotations it carries in it, the name Moira seems fit for a protagonist whose destiny and whose family's tragic fate is the focus of the novel.

\section{Across the Seas}

Yet, as the Canadian author herself points at, the classical references are not the only ones to make the name relevant for her character. It is also symbolic of the geography of the novel. Urquhart says:

When I was writing Away I chose the name Moira as the other name for one of my main characters, Mary, after she has been "away". I had no idea that there was a Greek connection there. But one of my friends is a classicist, and she says: "But Jane, that's the word for fate in Greek" or at least explains fate or something 
somehow related to fate. Interestingly, that one randomly chosen word changed the direction of the narrative because although I knew I wanted the family to come to Canada and I know I wanted them to settle near where my own family had settled (which was around the Madoc area in Hastings County, Ontario), what I didn't know, was that there was a lake there called Moira Lake. So, again, these revelations were like gifts given to me (Urquhart 2009: 4).

Moira is thus a place-name in Canada, though relatively obscure. It is the name of a village in Ontario, north of Belleville, together with that of the adjacent lake, the area where the O'Malleys first settle (Urquhart 2002: 152). The Black River which Brian mentions to his wife is a tributary to the Moira River, which feeds into Moira Lake (151). As Mary highlights to her Ojibway friend Exodus Crow, the lake where she meets her daemon-lover, the spirit of her dead sailor, bears the same name as herself (181), implicitly taking it as a sign that she was meant to emigrate there, that this was her destiny.

But Moira is also the name of a small town in Northern Ireland, although it is not mentioned in the novel. Situated in County Down, between Belfast and Lough Neagh, Maigh Rath, in its Irish form, would mean "the plain of prosperity" (Logainm.ie 2015), even though it may more accurately translate as "the plain of the wheels" (McKay and Muhr 2007: 56). This expresses quite ironically the whims of fate to which the O'Malleys have been prey, considering this book depicts the trials and tribulations of an Ulster family forced by the Famine to emigrate to Canada. Moira, Co. Down, is moreover the place of the Battle of Mag Rath in AD 637 (McKay and Muhr 2007: 56), noted among medieval Irish sources for the appearance of King Suibhne, known as Mad Sweeney because he lost his mind and went wandering for several years. The medieval Irish text was retranslated by Seamus Heaney in 1983, and the character of Sweeney has been used in a number of literary works, such as those of Flann O'Brien or T. S. Eliot for instance. Urquhart is rather likely to have read such works. It is during his wanderings, as he has been banished from the society of men and cursed by Saint Ronan, that Suibhne composes poetry. As Joseph Falaky Nagy remarks
The moment that a person receives the inspiration to see and speak like a poet can also be the moment that he is robbed of his identity, his autonomy, and his freedom from the tyranny of words, both his and those of others. This is precisely the moment undergone by the figure of Suibhne in the late Middle Irish text [...] (Nagy 1996: 2)

This portrayal of Suibhne parallels Mary in Urquhart's novel, since she is said to have the gift of eloquence (6), and her greatgranddaughter Esther, in whose mind the story is being replayed. All three female protagonists, Mary, Eileen and Esther, went astray, in one way or another, as did the king in the medieval episode.

As well as being the site of the battle in Ireland where Sweeney was cursed by a saint, Moira is thus also a settlement in Canada. The hamlet was actually named after the Earl of Moira, master of the village and territory in Ulster, and one of the dignitaries of the British Empire (Smith 2013: 217). The toponymy therefore replicates the emigrant experience of the protagonists of Away. It illustrates the idea of the ever-present landscape of home, which survives from one world to the next, since the settlers imprinted the landscape itself with their colonial experience by naming it after the world they had left behind. Urquhart is thus alluding to the viewpoint of the colonised through the geographical references too. She moves the focus from the colonial power to emigrants whose villages' names were first Anglicised, from Maigh Rath to Moira, to then be exported into newly-colonised territories in reference to aristocrats of the Empire, in both instances supplanting the native place-names, either Irish or First Nations. This shift of attention can only stem from a postcolonial impetus on the part of the author. Just like the term "away" to which Caterina Ricciardi refers, "Moira" is "a word whose meaning migrates from one world into another" (Ricciardi 2005: 71). In Urquhart's novel, the name of "Moira" is thus taken out of Northern Ireland to Canada: from the Moira, the shipwrecked vessel near Rathlin Island, to Moira Lake. This movement is embodied by Mary herself, since she emigrates from Ulster to Ontario and takes up the name. The emigrant experience is textually represented by the name Moira. 


\section{The Trace of a Ship}

Moira is in fact the name of the ship on which Mary's lover was a sailor. When she finds him among the prodigal wrecking of cabbages, teapots and whiskey after the storm and the sinking of the vessel, the only word he utters is "Moira" $(6,10)$. She takes it as a sort of baptism and takes on the name, but the reader later learns that it had been the ship's denomination. Mary's daemon-lover, whom she believes is from the Otherworld, was actually meant to go to Canada, since his ship, named Moira, had left Belfast and was bound for Halifax, Nova Scotia (35). The planned route of the ship and its crew parallels the later transatlantic journey of Mary and her family to Canada.

The name Moira is further laden with meaning, since it was also the name of a British warship in the nineteenth century. The HMS Moira was steering in the waters of Lake Ontario around the time at which the novel is set (Colledge and Warlow 2009: 265). It was also known as the HMS Earl of Moira and was obviously thus named after the son of the previously-mentioned Earl of Moira, Co. Down, who gave his name to the Canadian settlement. Incidentally, there was also a warship of the Royal Navy called the HMS Queen Mary, recalling several monarchs in British history, although it was build a century later than the HMS Moira.

The choice of this name for her protagonist is thus a way for the writer to re-appropriate it, away from colonial meanings. The name of a Royal Navy schooner becomes the name of a shipwrecked vessel off the Antrim coast which transformed the life of an Irish young woman who took it up. In a postcolonial fashion, Urquhart is subverting the name of the $H M S$ Moira since it turns into a wreck in the novel. Instead of a symbol of warlike colonial power, Moira becomes the new personality of a female protagonist from an oppressed minority.

\section{The Language Issue}

The ship imagery is also implicitly present in the Irish triad which Urquhart quotes as an epigraph to the book about the "three most short-lived traces". But while Urquhart uses a translation of rian luinge ar linn as "the trace of fish on a pool", it would be more accurately translated as "trace of a ship on a pool" (O'Rahilly 1922: 67). The phrase, present in the epigraph and as the title of the first part of the narrative, thus echoes both the departure from Ireland and Mary's encounter with her landlord Osbert Sedgewick by a tidepool. It is Osbert's encounter with Mary on the beach which makes him realise the consequences of his acts. Her refusal that he takes anything out of the microcosm of the rockpool for her facilitates his realisation that the tidepool is a whole world unto itself. His words to his brother when he says that "everything in the tidepools was connected, and that to remove life from them would be like tearing gold out of the earth" (92) forecast the later episode in the novel when, in Canada, Mary's children sell their plot of land to the same Sedgewick because a chip of gold was found on it, a transaction for which the family then incurred the "curse of the mines". Not only are the brothers the personifications of colonialism in Ireland, but they become so in Canada as well. These landlords can be perceived as the embodiments of colonialism, through their collecting and reification of Irish lore and objects, birds and other fauna (Bruce 2010: 116). The words rian luinge ar linn also echo a later scene, when Mary and Brian go to a wedding among the famine-stricken community. To Mary's amazement, the men form the shape of a ship with their bodies and one sheet for the sail, a ritual Brian tells her is usually done at wakes. The crowd answers "away, boys, away" and Mary is struck by this word "she thought was hers alone" (110-2).

The mistranslation of the phrase rian luinge ar linn thus exemplifies in the text the loss of language experienced by Mary in the narrative. The protagonist is in fact feeling lost between two languages, two cultures and two countries. Bharati Mukherjee Blaise, an Indian postcolonial writer, actually refers to the emigrant's new language as the "step-mother tongue" (Blaise 1981: 147), a phrase reflecting the complex relationship between the two. Mary is indeed an Irish-speaker and her husband, who is a hedge-school teacher, helps her learn English (59-62). Canada is not only a foreign country, but it also speaks a foreign language, this "stepmother tongue". The change of name therefore represents for Mary 
the trauma of emigrating to a land over the ocean, where the language spoken is different from her mother tongue. In Ireland, Brian was teaching Greek and Latin - two dead languages - to his pupils. But in Canada, it is in Irish that he is instructing the children, thus suggesting that his mother tongue is dying through the parallel with the classical languages. The loss of their land is paralleled by the loss of their language in the emigrants' experience:

\begin{abstract}
After [Mary] had been in the forest for several winters she told [Exodus] dark things; about the time [...] of the lost language and the empty villages and how the people who once sang were now silent, how the people who once danced were now still.

"It's true," said Brian bitterly. "Those who haven't died are scattered, and their voice is broken, their words are gone" (184).
\end{abstract}

Mary's loss of her original name crystallises this idea in the novel. Mary's other name, Moira, is in fact the Anglicised form of the name for Mary in Irish: Máire. Mary is the English name for a character who initially only speaks Irish and would therefore be called Máire by her community and relatives. When Mary takes on the name Moira it is not so much a change of identity than a return to her Irish roots, through what could be deemed as Urquhart's postcolonialism. Yet Moira is the Anglicised spelling of Máire, indicating the situational change for the character. Mary has moved to Canada, an English-speaking country where she however finds the comforting friendship of Exodus Crow, a fellow victim of British colonialism. The fact that her (new) name is Irish with an English spelling reflects her settling in Canada, a country which, at the time, belongs to the English crown and yet is not quite English, paralleling Ireland and its people. Mary's other name suggests both a return to her roots in reaction against colonialism and estrangement from her language.

Another aspect of postcolonialism in the work under examination is thus the language issue, ceist na teangan, through the triple aspect of the name of the female protagonist, which recalls the three Moirai of ancient Greece. In a typical postcolonial fashion, the female character, and her author, are subverting the Anglicisation by leaving behind Mary, to return to her Gaelic roots with her new name of Moira.

\section{Virgin Mary}

Mary being Irish in a nineteenth-century setting might lead one to think of the religious connotations of her name. The novel does not however foreground these connotations. The Catholic tradition sees the Virgin Mary as guide and protector on voyages. This comes from the Latin periphrasis to designate the mother of Christ, Stella Maris, which plays on the similitude between Maria (the Latin form of Mary) and the term for "sea", mare. The phrase means "star of the sea" and reflects Mary's transatlantic crossing in Away as well as her love of water. She comes from Rathlin Island, where she meets her lover by the sea of Moyle. Once she moves to the mainland upon marrying Brian, she continues to meet her daemon-lover by a small lake, Lough Crannog. When she emigrates to Canada, it is not long before she settles on the shore of Moira Lake to remain with her lover's spirit. This deep bond with the water is passed on in the family, since the novel ends with Esther who lived by Lake Ontario all her life. As is mentioned on the very first page of the novel, "There was always water involved", a few pages later explaining that "some of the girls in the family were unable to leave the lake at all. It was in them to seek forever the beaches they were born near and to walk in landscapes where something liquid glistened through the trees" $(3,5-6)$.

Apart from this association with water, Mary doesn't bear much similarity with her Christian namesake. Urquhart is subverting the religiousness of the name, since the entire narrative is based on "pagan" beliefs in otherworldly beings who take humans away to their realm. The novel centres around the folk belief in fairy abductions, according to which Mary is a changeling who has been substituted for the real woman who has been taken away to the Otherworld, far from the sanctity of the figure of the Virgin Mary. The Irish woman indeed tells her friend Exodus Crow stories from Ireland, that of the Fianna, the Children of Lir, Oisín who went to the Land of the Young and so on, which he believes and does not reject as fabrications, because "it was as if his own mother were telling the stories of the spirits" (179-80). On Rathlin Island, just after the storm 
and her encounter with the sailor, Mary is deaf to the prayers of the community and to the recommendations of Father Quinn, the island priest (48-9).

The author further subverts the name of the Virgin Mary, since she portrays an innocent young woman who meets a dying young man on the beach and becomes lovesick for him, in effect a virgin Mary. But although she is revered for her beauty by the islanders, she does not bear the same aura of sanctity as the Catholic mother figure, because of the pagan beliefs mentioned above (22-3). In the words of Libby Birch, "Mary, by becoming Moira, reclaims her ancient heritage" of "pre-Christian values" (Birch 1997: 117).

The tenuous religious connotation in the novel rather comes from the Native figure of Exodus Crow. He explains to Liam and Eileen that he got his name from the Book of Exodus:

I am called Exodus because my mother, who was taught to read by a churchman, lost interest in the Bible halfway through the Book of Exodus. She loved the name Exodus and was doubly disappointed therefore in this book. [...] My mother did not like this but she liked the sound of the word Exodus and wanted to give the name a better home. She called me Exodus (175).

Interestingly, the Book of Exodus is the chapter in the Bible in which Miriam, the Hebrew form of the name Mary, appears, as Moses' sister. The name Exodus also recalls the plight of the Irish emigrants that Mary, Brian and their family represent. Again, Urquhart is subverting the codes: it is the one who would be thought of as a "pagan", the character from the First Nations, who bears a name with religious connotation, while the Irish character, who would be expected to represent Catholicism, is stripped of any reference to the latter and embodies fairy beliefs and traditions.

\section{Conclusion}

"Never allow anything to change your name" says Eileen to her granddaughter Esther at the start of the novel (8), emphasising its significance and alluding to the story of her own mother who changed from Mary to Moira.

The name "Moira" which she chooses embodies the liminality of a character, standing between continents, cultures, languages, generations and lives. Mary is lost in the empty space in-between Ireland and Canada, and so has Eileen been. Jane Urquhart thus builds her narrative around the double identity of her protagonist. Moira could be seen as Mary's other self, since they are two sides of one heroine. This doubleness mirrors the changeling figure, which the islanders believe Mary has become: half-human, half-fairy, the creature of Irish tradition encapsulates the liminal situation of a character who is straddling the border of worlds, whether they be that of the humans and of the fairies, or that of the old Europe and of the New World. The changeling, who changes skins, parallels Mary in the novel, who changes names. The fairies abduct humans and take them away to an Otherworld: the folk figure represents the trauma of being robbed of one's land and identity and displaced to an unknown land. This fairy character thus embodies the liminal, psychological state of an exile. As Cynthia Sugars notes, Mary's "name change becomes a symbol for 'the change that takes you off to somewhere else'; it will condemn her to be always something of a migrant, in search of a home that does not exist" (Sugars 2003: 12).

This focus on the situation of victims of colonialism and on folk beliefs of these communities highlights Urquhart's postcolonial writing in Away, since the movement aims at drawing the focus onto the forgotten figures of colonial history, at shifting the attention from the coloniser to the colonised. Mary/Moira is the postcolonial embodiment of a loss of land and of a loss of language, which both lead to a loss of identity and to its subsequent reinvention. The classical etymology of her name points at her family's tragic fate, brought about by colonialism, while the topographical elements linked to it further evidence the postcolonial stance taken by the author. Displaced from Ireland to Canada, the name Moira parallels Mary's journey as well as the route of her dead sailor's boat. The imagery of ships and water is prominent in the novel and participates to the postcolonial argument through the subversion of British warships. This symbolism also alludes to the only religious aspect of Mary's name through the figure of the "star of the sea". Urquhart moreover subverts the expectations of the 
reader in terms of religious connotations, while the language issue furthers the metaphor of the emigrant experience and puts forward the triple nature of Mary's name, which recalls the three Moirai of ancient Greece and brings the reader full circle.

\section{Works Cited}

Bell, Marcia Anne. 1997. "Courting the Elements: Jane Urquhart's Novels and the Material Imagination". York University: PhD Thesis.

Birch, Libby. 1997. "The Irish Female Presence in Jane Urquhart's Fiction". Canadian Woman Studies/Les Cahiers de la Femme 17, no. 3. 115-9.

Blaise, Bharati Mukherjee. 1981. "Mimicry and Reinvention". The Commonwealth in Canada. Calcutta: Writer's Workshop.

Branach-Kallas, Anna. 2003. In the Whirlpool of the Past: Memory, Intertextuality and History in the Fiction of Jane Urquhart. Torún: Wydawnictwo Uniwersytetu Mikolaja.

Bruce, Barbara. 2010. "Collection, Canadian Nationalism and Colonial Resurgence in Jane Urquhart's Away". Resurgence in Jane Urquhart's Oeuvre, eds. Héliane Daziron-Ventura and Marta Dvořák. Bruxelles: Peter Lang. 109-28.

Colledge, J. J. and Ben Warlow. 2009 (4th ed.). Ships of the Royal Navy: the Complete Record of All Fighting Ships of the Royal Navy from the 15th Century to the Present. Newbury: Casemate.

Compton, Anne. "Romancing the Landscape, Jane Urquhart's Fiction". Jane Urquhart, Essays on Her Works, ed. Laura Ferri. Toronto: Guernica. 115-43.

Eliot, T.S. 1932. Sweeney Agonistes. London: Faber and Faber.

Ferri, Laura Forconi. Summer 2000. "Atmosphere, an Interview with Jane Urquhart". Descant 109. 146-156.

Fiontar. 2015. "Moira/Maigh Rath". http://www.logainm.ie/1411612.aspx

Goldman, Marlene. 2010. "Talking Crow: Jane Urquhart's Away". Resurgence in Jane Urquhart's Oeuvre, eds. Héliane Daziron-Ventura and Marta Dvořák. Bruxelles: Peter Lang. 129-44.

Heaney, Seamus. 1983. Sweeney Astray. London: Faber.

Karamanous, George E. 2013. "Fate". in Encyclopaedia of Ancient Greece, ed. Nigel Wilson. London: Routledge. 293-4.

Loomba, Ania. 2010 [1998]. Colonialism/Postcolonialism. London: Routledge.

McKay, Patrick, and Kay Muhr. 2007. Lough Neagh Places, Their Names and Origins. Belfast: Cló Ollscoil na Banríona.

Nagy, Joseph Falaky. 1996. A New Introduction to Buile Suibhne, The Frenzy of Suibhne Being the Adventures of Suibhne Geilt, a Middle Irish Romance, Subsidiary series 4. London: Irish Texts Society/Cumann na Scríbheann nGaedhilge.

O’Brien, Flann. 1939. At Swim-Two-Birds. London: Longmans.

O'Rahilly, Thomas. 1922. Miscellany of Irish Proverbs. Dublin: Talbot Press.

Ricciardi, Caterina. 2005. "Away and the Meanings of Colonization". Jane Urquhart, Essays on Her Works, ed. Laura Ferri. Toronto: Guernica. 65-77.

Scodel, Ruth. 2010. An Introduction to Greek Tragedy. Cambridge: Cambridge University Press.

Smith, Donald B. 2013. Mississauga Portraits: Ojibwe Voices from Nineteenth-Century Canada. Toronto: University of Toronto Press.

Sugars, Cynthia. Spring 2003. "Haunted by (a Lack of) Postcolonial Ghosts: Settler Nationalism in Jane Urquhart's Away". Essays on Canadian Writing 79. 1-32.

Urquhart, Jane. 2002 (1993). Away. London: Bloomsbury.

May 1995. Interview with Elaine Kalman Naves. "Home from Away". Books in Canada vol. 24. no. 4. 7-13. 
2009. Interview with Anne-Sophie Letessier. Appendix to "Space and Palimpsest: The Poetics of Landscape in Jane Urquhart's Away and Changing Heaven". Université de Nantes: MA Dissertation.

Wyile, Herb. 1999. “"The Opposite of History is Forgetfulness': Myth, History and the New Dominion in Jane Urquhart's Away". Studies in Canadian Literature/Études en littérature canadienne 24, no. 1. 20-45.

Received 16 September 2015 Last version 18 October 2015

Audrey Robitaillié studied for her PhD under joint supervision at Queen's University Belfast and Université de Caen Basse-Normandie, researching the folk figure of the changeling in contemporary Irish literature. Her general area of research is the reuse of Irish folklore in literature. 